Neoplastic diseases are among the most common causes of death. The quality of life in neoplastic disease depends on the type of neoplasm, level of progression, location, treatment possibilities and prognosis. Cancer reduces the quality of life at the advanced stage of disease. At this time patients feel pain and suffering. Palliative care is used in the terminal phase of neoplastic disease. It includes overall care of an incurable patient and her/his family. The main objective of palliative care is meeting somatic and psycho-social requirements. Recently, more and more physicians dealing with oncological patients are moving away from treatment of the patient like an object. They pay attention to a subjective approach to treatment outcomes that are felt by the patient. The model of medicine is becoming a holistic one and during examination physicians pay attention to the patient's physical and mental state, economic condition, social situation, feelings or lack of complaints more often. Research on quality of life is becoming a vital part of medical examination.

Key words: quality of life, palliative care, terminal phase of neoplastic disease.

\section{Selected aspects of palliative care and quality of life at the terminal stage of neoplastic disease}

\author{
Paulina Farbicka', Andrzej Nowicki ${ }^{2}$
}

${ }^{1}$ Clinical Emergency Ward, $10^{\text {th }}$ Clinical Military Hospital with Outpatient Clinics in Bydgoszcz, Poland

2Department of Oncological Nursing, L. Rydygier Collegium Medicum in Bydgoszcz, Nicolaus Copernicus University in Torun, Poland

\section{Introduction}

Diagnosis of neoplastic disease often arouses fear and negative associations in patients because of the serious prognosis. The chance of survival of patients with malignant neoplasms has improved significantly because of progress in medical research in recent years. Cancer is already not associated with death only; people more and more often think about it as a chronic disease [1].

Neoplastic diseases are among the most common causes of death. Worldwide about 11 million cases are diagnosed each year with the mortality rate about 7 million. The incidence of neoplastic diseases increases with age as in the case of chronic neurological diseases and diseases of the cardiovascular system [2, 3]. The American Cancer Society estimates the number of new diseases and deaths from neoplasms in the United States every year. 1596670 new cases and 571590 deaths were estimated in 2011 [4], while in Poland 131063 new cases and 93060 deaths were observed in 2008 [5].

Reducing the mortality rate and frequency of disease recurrences and improving body functionality are traditional goals of treatment. Neoplastic disease affects all spheres of human activity so the necessity of assessment of the quality of life is emphasized in the case of patients treated oncologically. The treatment programme depends on type, location and stage of cancer. The treatment process starts with diagnosis of disease. Obtained results of the histopathological examination and molecular marker test enable one to choose the appropriate method. Various techniques are applied. Radiotherapy consists in irradiation of the tumour, surrounding tissues and lymphatic nodes. Surgery is another technique which consists in removing the tumour together with a healthy tissue margin or whole organ with growing cancer. Chemotherapy is the next kind of treatment and consists in administering medicines in large doses at given time intervals. The choice of radical treatment depends on cancer stage and its susceptibility to treatment. Palliative treatment is used in the advanced stage of disease (the term comes from the Latin: pallium - cloak, palliare - to cloak). It is an approach aimed at relieving or modifying signs and symptoms of progressive chronic disease resistant to curative treatment with unfavourable prognosis. It also concerns advanced neoplastic disease. Oncological treatment produces many adverse symptoms but it should be remembered that most patients cope with disease in an adaptive way $[1,6]$.

Earlier diagnosis of cancer and increasing effectiveness of treatment methods is a condition for improving outcomes. Cooperation of physicians who conduct surgical, systemic (chemical and hormonal) treatment and radiotherapy is becoming very important. This is an integrated approach. Treatment that is the best from a medical point of view and most reasonable economically 
is more and more often selected. However, it is necessary to avoid the situation where efforts towards economical rationalization could cause reduction in the range of health services [3].

The quality of life in the case of neoplastic disease depends on the type of cancer, its stage and location, possibilities of treatment and prognosis. Malignant cancer makes the quality of life worse, most often in the advanced stage when people with this disease feel pain and suffering. Diagnosis alone arouses dread and feelings of helplessness which significantly diminish the level of quality of life. Developing malignant cancer often leads to behavioural disturbances that need psychological and psychiatric intervention. Patients feel fear of death, worry about the fate of their relatives, feel dejection, have a sense of injustice, and even fall into depression. Calming and support are extremely important for all patients [7, 8].

The attitude towards cancer is starting to change with the development of new treatment methods. The American Cancer Association was founded in 1913 and initiated the first public campaigns. This action was directed towards society in order to improve knowledge about the disease, its symptoms and prophylaxis [9]. Despite numerous campaigns many people still downplay symptoms of the disease, and often visit a specialist too late. The attitude of society to psychiatric treatment is a serious obstacle. Psychotherapy is perceived as something embarrassing in certain social groups. But attitudes are changing and more and more people treat disease as one element in the treatment process. In 1951 Shands and his collaborators described psychological mechanisms in patients with cancer. They observed that com munication with the patient becomes more difficult with progression of the disease [10]. According to Modlinska and her colleagues the fearful reaction to neoplastic disease projects onto quality of life significantly in patients above 65 years old at the terminal phase of disease while in older patients problems with physical activity are prevalent [11].

\section{Phases of neoplastic disease}

Working with people at the terminal phase of neoplastic disease needs extraordinary dedication to others and also patience and understanding. Today the demand of professional assistance at the time when the disease becomes incurable puts new challenges before the health care systems around the whole world. This challenge is qualitative in its nature (because of raising expectations and treatment possibilities) and also quantitative - because of the aging of societies and increasing morbidity of diseases of respiratory and cardiovascular systems as well as neoplasms [12].

In the case of incurable neoplastic disease a several-week, sometimes several-month period when the patient is close to death is observed. At this time palliative treatment is most important when the total pain is alleviated mainly. The advanced stage of chronic disease begins at the moment when the patient is qualified for palliative care. Due to the clinical state and forecasted longevity of life this stage is divided into three phases. The pre-terminal phase is the first one, in which the patient's general state is quite good. At this time the care relies on periodic medical and nursing consultations in a palliative medicine clinic. The terminal phase is the next one, when the patient's general state begins irreversible deterioration that increases at a visible pace. In most cases the patient no longer leaves the house. This period usually lasts for several weeks. Treatment is limited to be the least burdensome to the patient. The dying phase (agony) is the last one, which immediately precedes the death of a patient. It takes several days, sometimes a few hours. At this time multi-organ failure, metabolic disorders and disturbances of consciousness occur [13].

When may we talk about the end of life? Terminology is the main problem in this domain. It is said that people in the advanced incurable phase of neoplastic disease are qualified for terminal care, hospice, or palliative care at the end of life. Studies of people dying from cancer conducted in the Netherlands and Italy prove that escalation of symptoms and disability occurs three months before death regardless of age or type of neoplasm. According to the Agency for Healthcare Research and Quality the end of life may be defined in various ways: firstly, as active dying when we can expect death within several hours or days; secondly, as a "readiness"; and thirdly, as disease progression that is specified by objective examinations results. The end of life can also depend on the clinical prognosis [14].

\section{Quality of life in the terminal phase of neoplastic disease}

Special interest in the problem of quality of life in medicine appeared in the 1970s. The medical and non-medical outcomes of health care in the domain of oncology, psychiatry, rheumatology, internal medicine and gerontology began to be assessed. Therefore, a new concept of a model for medicine was created (holistic model) which was responsible not only for prolongation of the patient's life but was also responsible for making the patient's life active and similar to the period before disease $[15,16]$.

According to the WHO definition the quality of life means "the way individuals perceive their living position in a cultural context and value system in which they live and in relation to their tasks, expectations and standards set by environmental determinants". WHO includes physical and mental conditions, degree of independence, social relationships, environment, religion, beliefs and views in the scope of the quality of life $[16,17]$.

In relation to neoplastic disease Knippenberg notes that objective indicators of patient quality of life (assessed by physicians) are replaced by subjective assessments by patients. It is not uncommon that there are significant differences in assessing the quality of life based on objective and subjective criteria. Siergist J. believes that research on the quality of life in the case of chronic diseases complements data obtained from diagnostic examinations and laboratory tests. The author states that research on the quality of life fulfils different functions in medicine and may indicate needs of patients previously unrecognized by the physician related to the provision of medical care outside the hospital. In addition, it shows the patient's point of view, which may differ from professional medical knowledge. Subjective assessments of patients can be a source of additional information that could be useful for therapeutic decision making [16]. 
Quality of life in oncological patients is a process that changes in time. Anxiety and depression often occur in these patients. They arise from the fear of death and also from fear about the fate of relatives. Some diagnostic and treatment methods also raise fear. It often happens that the patient is not informed sufficiently about their character and effects. On the one hand, hope about possible decrease of symptoms or complete remission of disease affects quality of life in patients with neoplasms. On the other hand, there is anxiety about appearance of additional, even more distressing symptoms [7]. The communication between physician and patient is a very important factor affecting quality of life at the terminal phase of neoplastic disease. Many patients die with pain and other distressing symptoms that are not managed in the right way. These patients often receive onerous, aggressive care that makes their quality of life worse. Skills of empathic listening to complaints of the patient and relatives, touch and also silence of persons from the medical staff or volunteers play an important role [6]. Until recently, estimates of overall survival and disease-free survival were the primary criteria for assessment of oncological treatment effectiveness. Currently, attention is drawn to additional elements, e.g. impact of the disease and the applied treatment on the functional and mental state of patient. To assess the quality of life several questionnaires are often used at the same time. This follows from the fact that it is difficult to create one survey form that enables assessment of the patient as a "whole" - her/his somatic and mental state, social relationships, and physical well-being [7].

There are various types of questionnaire. OLQ-C30 is one of them. This is a questionnaire developed in order to assess quality of life in patients with neoplasms. It was created by the Quality of Life Group established at the European Organisation for Research and Treatment of Cancer (EORTC). This questionnaire has been translated and approved in 81 languages. It consists of five parts and evaluates five levels of patient activity: physical, emotional, cognitive, social and living condition. The first three parts define the severity of symptoms (pain, fatigue, nausea and vomiting), overall assessment of health status and quality of life. In addition, individual questions are formed to assess the intensity of other associated symptoms (constipation, diarrhoea, shortness of breath, sleep disturbances). Apart from that, the assessment of disease influence on patient economic condition is performed by the patient. The questionnaire does not include the type and location of cancer. Separate modules are developed in order to assess quality of life for patients with specific cancers, e.g. a module for patients with lung carcinoma (QLQ-LC13). The QLQ-C15-PAL questionnaire is a shortened version of QLQ-C30 that has been developed for assessment of quality of life for patients undergoing treatment in palliative care units. This questionnaire is used for research on advanced incurable neoplasms with median survival about several months $[7,18,19]$.

Functional Assessment of Chronic Illness Therapy (FACIT) is a set of tools for measurement of quality of life related to health condition in patients with various chronic diseases. The FACIT questionnaire is derived from a group of FACT questionnaires (Functional Assessment of Cancer Therapy).
FACT-G (Functional Assessment of Cancer Therapy - General) is the general version of this tool. It was developed and approved more than 20 years ago. It does not include the type of neoplasm. It evaluates physical condition, social/family life, emotional state and everyday activity. Each question is rated on a scale from 0 to 5 , where 0 is the lowest and 5 the highest quality of life. There are over 50 different FACT questionnaires. Some of them exist in over 50 language versions, which allows international comparison of people from various environments. Separate modules are used for assessment of quality of life in patients with a specific neoplasm, e.g. FACT-B (Functional Assessment of Cancer Therapy Breast) [20].

The introduction of palliative care early in the disease together with curative treatment is essential. About $25 \%$ of patients are referred to palliative care in the last week of life. This is related to concern of caregivers that the patient does not fall into depression. Palliative care is often associated with poor prognosis and the proximity of death. The recommendations contained in the Council of Europe Recommendations on palliative care indicate the advisability of referring patients to palliative care institutions for patients with chronic, progressive, limiting life diseases as early as possible, even during curative treatment [6]. The hospice is the place where palliative care is used most often.

The improvement of quality of life has a positive influence on the positive course of the disease. According to Jocham and associates, patients undergoing palliative care often complain of nausea and vomiting (5-91\%), cancer pain (11-84\%), breathlessness (21-64\%), fear and depression (27\%). Johnsen in similar research showed that the most common complaints of patients were related to fatigue (57\%), limitations in performing social roles (51\%), insomnia (48\%) and pain (39\%). Nausea and vomiting can cause many complications, e.g. metabolic acidosis, aspiration pneumonia, hypokalaemia. Pain occurs in $70-80 \%$ of patients in the terminal phase of disease and its causes are diverse. Control of pain is a primary goal of home treatment [21]. Pain that occurs in patients with advanced neoplastic disease is often of chronic and stable nature. Acute pain occurs periodically and is related to, for example, painful therapeutic and diagnostic procedures requiring a separate procedure. As many as $80 \%$ of patients complain of having more than one kind of pain. Pain is divided into nociceptive, neuropathic and mixed type of pain according to their pathogenesis. The first one is caused by stimulation of pain receptors. Bone pain and visceral pain are observed in $30-40 \%$ of patients with neoplasms. Neuropathic pain arises following damage of nerve fibres included in the pain pathways. As a rule it is more difficult to treat, and is diagnosed in $30-40 \%$ of patients. Mixed pain is pain of both nociceptive and neuropathic nature [22]. This type of pain is hard to relieve in 10-15\% of patients despite progress in pain treatment.

Patients suffer from halitosis in the terminal phase of neoplastic disease. This is due to lesions developing in the respiratory and digestive systems. For this reason, patients experience discomfort and this can lead to avoidance of contacts with others. Xerostomia is the next problem. It is caused, among others, by reduction in secretion of saliva, chemother- 
apy, radiotherapy or medication. Patients in the terminal stages of cancer may have stomatitis. The patient feels burning, pain, and difficulties in swallowing. Taste disturbance is another problem faced by patients during the last weeks of life. In this period patients feel a metallic, bitter taste in the mouth. This increases the reluctance to eat. The lack of appetite leads to cachexia. The quality of life is reduced along with progress of neoplastic disease. This leads to loss of body weight, which is associated with decreased immunity and depression. Patients lose their independence, and need help from relatives from their neighbourhoods [23].

Diarrhoea may occur in the last weeks of life. Administration of laxatives necessary in case of constipation (the result of using opioids, radiotherapy, chemotherapy, or dietetic mistakes) is a cause of diarrhoea. Patients with advanced neoplastic disease are at risk of developing bedsores. They lead to additional pain. Itching is a further problem. It is caused by dried skin and also bacteria and fungi causing inflammatory changes. Lymphoedema is a complaint which is manifested by increased weight of the limb, causing restriction of movement and sensory disturbances. Insomnia and fatigue are problems that reduce quality of life. They cause additional weakness and reluctance to exercise [23].

\section{Palliative care}

According to the WHO, "Palliative care is a way of improving quality of life of patients and their families facing the problems associated with life-threatening disease by preventing and alleviating suffering, early identification of problems, the best assessment and treatment of pain as well as other physical, psycho-social and spiritual problems" [24]. Palliative care is aimed at meeting somatic, psycho-social and spiritual needs by early identification of needs and threats, preventing and alleviating suffering and supporting families during illness of a loved one. The aim is to improve the quality of life. End of life care is used in patients who are close to death (last weeks/days of life). At this time patients need professional care and palliative treatment [6].

The second edition of the National Consensus Project Clinical Practice Guidelines for Quality Palliative Care was published in 2009. According to that publication palliative care is integrated medical care provided by a team of specialists in many fields such as physicians, nurses, clergy, social workers and other health care workers focused on aiding in relief of suffering and giving support to ensure the best quality of life of people with incurable illness and their families. It should be conducted until the death of the patient and involve the patient's family during the mourning [25].

About $90 \%$ of patients under palliative care are persons with advanced neoplastic disease. The basic form of palliative care is home care and is exercised by a doctor, nurse, psychologist, physiotherapist and social worker mainly. The patient has the right to use medical services offered by the family doctor and other specialists but due to low mobility and frequent contact with the hospice physician chooses the latter $[24,26]$. There was a decrease in the number of deaths at home in the second half of the twentieth century. The number of cancer patients dying at home decreased from $37 \%$ in 1965 to $27 \%$ in 1987 . According to the Office for
National Statistics 58\% of deaths occur in hospitals, $18 \%$ at home, $17 \%$ in nursing homes, $4 \%$ in hospices and $3 \%$ in other places [27]. According to Yao and colleagues dying at home is regarded as the main component of a "good death". They conducted research on 374 patients dying from cancer and compared a group of patients dying from cancer at home with a group of patients dying in a hospital palliative care unit. They concluded that the comfort of patients dying at home was higher compared to patients dying in hospital. However, the assessed level of physical comfort before death at home was lower compared to the comfort of the hospital. Early integration of palliative care to standard anticancer therapy can contribute to better preparation of the patient for death [28]. These results are confirmed by a study by Curtis et al. The authors evaluated the quality of death and dying by the Quality of Death and Dying (QODD) questionnaire. It consisted of 31 items, focused on the last seven days of life of the dying person. A family member assessed the quality of death and dying on a scale from 0 (terrible) to 10 (almost perfect). The results showed that the quality of dying was higher in the environment known to the patient. According to Hunt, the elements of a good death include: control of physical symptoms, acceptance of the disease and its diagnosis, maintaining hope, satisfaction with life and peaceful death at home. McNeil suggests that patients want to die at home because they intend to have control over their lives in the home environment. On the other hand, they may feel angry that the hospital should not be used for them [27].

The head of the medical unit of palliative care should be a physician certified in palliative care. Due to the insufficient number of professionals in this field this function can also be served by physicians of another speciality but experienced in palliative care and having completed relevant courses. The nurse employed in the palliative care should be specialized in this area or complete a qualification course (or perfecting of palliative care). Other members of the multidisciplinary team are recommended to have received training in palliative care making work with the patient and her/his family easier [24].

Home hospices are an organizational form of palliative care where patients staying at home may use equipment rented from the hospice. The interdisciplinary team members visit patients at home depending on the needs. In-patient palliative care includes in-patient hospices and palliative care wards. The latter are usually placed in general hospitals. Inpatient palliative care units should be located so there is one for two or three counties. They allow medical procedures to be carried out that cannot be done at home, and ensure specialized care. These units can conduct research and training. Outpatient palliative care is for patients in good general condition, but with limited mobility. Day care centres are for patients who permanently reside in their homes and are visited one or more times a week during the day. In addition, supervision may be exercised by a hospital support team. A home hospice for children provides palliative care for children with life limiting illnesses living in homes [24].

One concept of the practice of palliative medicine is to make it an integral part of oncology. For development of this model, the proposals of the European Society for Medical 
Oncology (ESMO), according to which palliative care and supportive treatment are defined as oncologists' obligation and duty, can be considered. The ESMO draws attention to the need to implement the so-called philosophy of continuity of care, professional assistance both medical and nursing, integration of oncological and palliative treatment, and meeting of physical and existential needs [29].

A document entitled Better Palliative Care for Older People edited by Davies and Higginson. was published in 2004, under the auspices of the European section of the WHO. According to the report, older people should be covered by professional care. In addition, the document emphasizes the development of home care, which helps to avoid many unnecessary hospitalizations. Attention is drawn to assuring holistic care, respect for patient autonomy and support for caregivers [30].

\section{The problems of palliative care in Poland}

In Poland, 90 thousand people die from neoplastic disease each year, $55.3 \%$ in hospital and $44.2 \%$ at home. Due to the aging population and due to the expected increase in morbidity and mortality from cancer, the number of people requiring palliative care will increase. Therefore, it is important to ensure good quality care for these people, in accordance with the standards of the World Health Organization [31].

Palliative care in Poland has over twenty years of tradition. It is treated as a separate specialty carried out by highly specialized centres. Palliative care is financed from public funds. Palliative medicine has been a clinical specialty for doctors and nurses since 1999 [29]. Under-funding is the most important problem of palliative care. In recent years it has concerned in-patient institutions, which led to elimination of individual palliative care wards in 2008. The situation improved with the support of the Ministry of Health in mid2008. Another problem is the lack of adequately prepared staff. The number of physicians who specialize in palliative care is still too small. There are no established standards. A project on regulation of standards in palliative care was submitted to the Ministry of Health in 2004. It still has not been put into practice. Additionally, in many provinces palliative care units are located in old buildings that require renovation. There are not enough beds for patients and there are no funds for renovation and modernization. The changing conditions of contracts cause instability in the functioning of palliative care [24].

Inadequate funding is a barrier to ensuring good care in the Polish conditions. The majority of outpatient palliative clinics make a financial loss, and contracts with the NFZ (National Health Fund) are insufficient. Patients with complex problems land in the in-patient palliative care units. These are patients who not only suffer from pain and other symptoms associated with disease, but are also burdened with additional disorders. In Poland, according to the law on universal health insurance, palliative care is financed from public funds as a separate provision of health. Palliative care is financed by the National Health Fund in the scope of: palliative home care team/home hospice, palliative medicine ward/in-patient hospice, home hospice for children and palliative care outpatient clinic. Hospital support teams and pal- liative day care centres are not funded by the NHF, hence the small number of them in the country $[24,26]$.

In per capita terms the amount of expenditures from the National Health Fund for palliative care remained constant in 2005-2008 and was 3.53 PLN per patient. This amount increased in the second half of 2008 (5.54 PLN) and in 2009 (6.73 PLN). Palliative care units also functioned through additional sources of financing such as funds derived from local governments and from NGOs (associations and foundations). The overall amount of these funds is not known. The use of EU funds remains small. A modest financial outlay may come from programmes of the Ministry of Health [24].

The implementation of the National Cancer Control Programme is expected to integrate palliative care with oncology in Poland. The introduction of a hospital support team in all oncological hospitals was considered an important element. Its task is to ensure the introduction of palliative care and nursing care at an early stage of neoplastic disease, reduce patient distress in the hospital, and facilitate a smooth transition from hospital to home care [29].

The authors declare no conflict of interest.

\section{References}

1. Machnik-Czerwik A. Funkcjonowanie na płaszczyźnie psychofizycznej a jakość życia chorych onkologicznie. Psychoonkologia 2010; 2: 55-9.

2. Yancik R, Ganz PA, Varricchio CG, Conley B. Perspectives and comorbidity and cancer in older patients: approaches to expand the knowledge base. J Clin Oncol 2001; 19: 1147-51.

3. Lutostańska I, Mrówczyńska E, Mazurkiewicz B, Stachowiak A. Analiza Zintegrowanego Systemu Opieki nad osobami umierającymi na oddziale opieki paliatywnej - wszechstronna ocena potrzeb pacjentów o okresie terminalnym choroby nowotworowej. Med Paliat 2010; 2: 100-6.

4. Siegel R, Ward E, Brawley O, Jemal A. Cancer statistics, 2011: the impact of eliminating socioeconomic and racial disparities on premature cancer deaths. Cancer J Clin 2011; 61: 212-36.

5. Wojciechowska U, Didkowska J, Zatoński W. Nowotwory złośliwe w Polsce w 2008 roku. Centrum Onkologii - Instytut im. M. Skłodowskiej-Curie, Warszawa 2010.

6. Łuczak J, Kotlińska-Lemieszek A. Opieka paliatywna/hospicyjna/medycyna paliatywna. Nowiny Lek 2011, 80: 3-15.

7. Łaszczewska V. Jakość życia pacjentów z chorobą nowotworową. Prz Urol 2002; 2: 74-7.

8. Bąk-Sosnowska M, Michalak A, Bargiel-Matusiewicz K, TrzcienieckaGreen A. Psychologiczne aspekty kontaktu z pacjentem onkologicznym oraz jego rodziną. Psychoonkologia 2003; 7: 121-6.

9. Holland JC. History of psycho-oncology: overcoming attitudinal and conceptual barriers. Psychosom Med 2002; 64: 206-21.

10. Shands HC, Finesinger JE, Cobb S, Abrams RD. Psychological mechanisms in patients with cancer. Cancer 1951; 4: 1159-70.

11. Modlińska A, Buss T, Krakowiak P. Ocena jakości życia osób w wieku podeszłym w terminalnym okresie choroby nowotworowej. Przegl Lek 2009; 66: 479 - 84 .

12. Flakus J. Pozamedyczne aspekty opieki paliatywnej. Działalność hos picjów w opinii różnych grup społecznych. Med Paliat 2009; 1: 33-9.

13. Hebanowski M, de Walden-Gałuszko K, Żylicz Z. Podstawy opieki paliatywnej w chorobach nowotworowych. PZWL, Warszawa 1998.

14. Bennett MI, Davies EA, Higginson IJ. Delivering research in end-oflife care: problems, pitfalls and future priorities. Palliat Med 2010; 24: 456-61. 
15. Owczarek K. The concept of quality of life. Acta Neuropsychologica 2010; 8: 207-13.

16. Tobiasz-Adamczyk B. Wybrane elementy socjologii zdrowia i choroby. Wydawnictwo Uniwersytetu Jagiellońskiego, Kraków 2000; 233-51.

17. Steller B. Jakość życia jako pojęcie subiektywne i wielowymiarowe. Pielęg Pol 2001; 2: 227-33.

18. de Walden-Gałuszko K, Majkowicz M. Ocena jakości opieki paliatywnej w teorii i praktyce. Akademia Medyczna, Gdańsk 2000.

19. Jasińska M, Tracz M, Kurczewska U, Orszulak-Michalak D. Assessment of change of quality of life in hospitalized terminalny ill cancer patients. Wspolczesna Onkol 2010; 14: 333-9.

20. www.facit.org (31.05.2012r.).

21. Czerwik-Kulpa M, Chylińska J. Quality of life in palliative care. Acta Neuropsychologica 2010; 8: 244-62.

22. Kotlińska-Lemieszek A, Bączyk E, Deskur-Śmielecka E, Łuczak J. Bóle u pacjenta z chorobą nowotworową - diagnoza kliniczna jako warunek prawidłowego postępowania. Nowiny Lek 2011, 80: 16-21.

23. Glińska J, Adamska E, Brosowska B, Lewandowska M. Problemy fizyczne chorych w terminalnej fazie choroby nowotworowej a wsparcie społeczne ze strony personelu pielęgniarskiego. Problemy Pielęgniarstwa 2009; 17: 190-8.

24. Ciałkowska-Rysz A. Sytuacje i wyzwania opieki paliatywnej w Polsce. Med Paliat 2009; 1: 22-6.

25. National Consensus Project. Clinical practice guidelines for quality palliative care 2009. www.nationalconsensusproject.org (20.03.2012r.).

26. Ciałkowska-Rysz A, Gottwald L, Kaźmierczak-Łukaszewicz S. Choroby wspótistniejące $z$ chorobą nowotworową u osób objętych domową opieką paliatywną. Med Paliat 2010; 2: 162-6.

27. Paddy M. Influence of location on a good death. Nurse Stand 2011; 26: $33-6$

28. Yao CA, Hu WY, Lai YF, Cheng SY, Chen CY, Ciu TY. Does dying at home influence the good death of terminal cancer patients? J Pain Symptom Manage 2007: 34: 497-504.

29. Jarosz J, Wikłacz R, Grzeszczak M, Czerwik-Kulpa M, Smolik B, Opieka J, Markowska-Gąsiorowska A, Majewska M. Ocena zapotrzebowania na działalność szpitalnego zespołu wsparcia w szpitalu onkologicznym. Medy Paliat 2010; 2: 18-24.

30. Davies E, Higginson I. Belter palliative care for older people. WHO Regional Office for Europe 2004.

31. Kaczmarek MS, Żółtak-Bączkowska K, Szymkowicz-Kowalska M, Karakiewicz B. Analiza problemów medycznych i psychospołecznych pacjentów objettych opieką Hospicjum Domowego w Szczecinie w 2007 r. Med Paliat 2011; 2: 81-6.

\section{Address for correspondence}

Andrzej Nowicki, Ass. Prof.

Technikow 3

85-801 Bydgoszcz

e-mail: anow1 xl@wp.pl

Submitted: $\quad 16.02 .2012$

Accepted: $\quad 15.06 .2012$ 